\title{
B Cell Deficient Mice Are Protected from Biliary Obstruction in the Rotavirus-Induced Mouse Model of Biliary Atresia
}

\author{
Amy G. Feldman ${ }^{1 *}$, Rebecca M. Tucker ${ }^{2}$, Erika K. Fenner², Roberta Pelanda ${ }^{3}$, Cara L. Mack ${ }^{1,2}$ \\ 1 Department of Pediatrics, Section of Pediatric Gastroenterology, Children's Hospital, Colorado, United States of America, Aurora, Colorado, United States of \\ America, 2 Departments of Medicine and Immunology, University of Colorado School of Medicine, Aurora, Colorado, United States of America, 3 Integrated \\ Department of Immunology, National Jewish Health, Denver, Colorado, United States of America
}

\begin{abstract}
A leading theory regarding the pathogenesis of biliary atresia (BA) is that bile duct injury is initiated by a virus infection, followed by an autoimmune response targeting bile ducts. In experimental models of autoimmune diseases, $B$ cells have been shown to play an important role. The aim of this study was to determine the role of $B$ cells in the development of biliary obstruction in the Rhesus rotavirus (RRV)-induced mouse model of BA. Wild-type (WT) and B

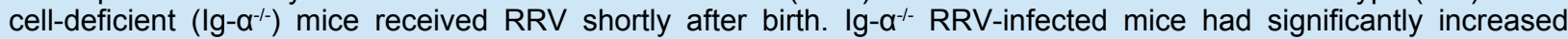
disease-free survival rate compared to WT RRV-infected BA mice $(76.8 \%$ vs. $17.5 \%)$. In stark contrast to the RRVinfected BA mice, the RRV-infected Ig- $\mathrm{a}^{-1}$ mice did not have hyperbilirubinemia or bile duct obstruction. The RRVinfected Ig- $\mathrm{a}^{-1-}$ mice had significantly less liver inflammation and Th1 cytokine production compared to RRV-infected WT mice. In addition, Ig- $\mathrm{a}^{-/}$mice had significantly increased numbers of regulatory $\mathrm{T}$ cells (Tregs) at baseline and after RRV infection compared to WT mice. However, depletion of Tregs in $\mathrm{Ig}^{-\mathrm{a}^{-1}}$ mice did not induce biliary obstruction, indicating that the expanded Tregs in the $\mathrm{lg}-\mathrm{\alpha}^{-/}$mice were not the sole reason for protection from disease. Conclusion: B cell deficient Ig- $-^{-/-}$mice are protected from biliary obstruction in the RRV-induced mouse model of BA, indicating a primary role of $B$ cells in mediating disease pathology. The mechanism of protection may involve lack of $B$ cell antigen presentation, which impairs T-cell activation and Th1 inflammation. Immune modulators that inhibit B cell function may be a new strategy for treatment of BA.
\end{abstract}

Citation: Feldman AG, Tucker RM, Fenner EK, Pelanda R, Mack CL (2013) B Cell Deficient Mice Are Protected from Biliary Obstruction in the RotavirusInduced Mouse Model of Biliary Atresia. PLoS ONE 8(8): e73644. doi:10.1371/journal.pone.0073644

Editor: Christine Beeton, Baylor College of Medicine, United States of America

Received May 31, 2013; Accepted July 19, 2013; Published August 21, 2013

Copyright: $\odot 2013$ Feldman et al. This is an open-access article distributed under the terms of the Creative Commons Attribution License, which permits unrestricted use, distribution, and reproduction in any medium, provided the original author and source are credited.

Funding: Mack: NIDDK 1 RO1 DK078195; Children's Hospital Colorado Research Institute; Pelanda: R01 Al052310; Feldman: T32-DK06700907; Cystic Fibrosis Foundation, FELDMA10BO. The funders had no role in study design, data collection and analysis, decision to publish, or preparation of the manuscript.

Competing interests: The authors have declared that no competing interests exist.

*E-mail: afeldman@luriechildrens.org

\section{Introduction}

Biliary atresia (BA) is the leading cause of neonatal cholestasis, occurring in approximately 1 out of 10,000 live births in the United States [1]. BA entails a progressive, inflammatory injury of bile ducts, leading to fibrosis and obliteration of both the extrahepatic and intrahepatic bile ducts $[2,3]$. At the time of diagnosis, a Kasai portoenterostomy is performed in an attempt to re-establish bile flow. Despite this surgical intervention, the intrahepatic bile duct injury continues, leading to cirrhosis and the need for liver transplantation during childhood in the majority of patients [4,5]. A better understanding of the immune mechanisms associated with BA has the potential to lead to new therapies aimed at halting injury to the intrahepatic bile ducts and preserving liver function.
Multiple theories have been proposed as to the pathogenesis of BA, including viral infection [6-8], autoimmune mediated bile duct destruction [2,9] and abnormalities in bile duct development [10]. It is hypothesized that an initial virus infection induces an autoreactive T cell-mediated injury to bile duct epithelium which persists even after virus is cleared [2]. In order to perform mechanistic studies, the Rhesus rotavirus (RRV)-induced mouse model of BA has been employed by many investigators [11-14]. In this model, the bile duct injury is associated with Th1-mediated inflammation and specifically with bile duct epithelial autoreactive T cells $[15,16]$. Much less is known about the role of $B$ cells in the pathogenesis of BA. Many experimental models of autoimmune diseases have demonstrated an important role of $B$ cells in disease pathogenesis [17-20] and trials of B-cell modulating agents are being conducted in human autoimmune diseases [21]. In both 
humans and in the mouse model of BA, periductal immunoglobulin deposits and circulating autoantibodies have been described $[15,22]$. One such autoantibody reactive to cytosolic enolase from bile duct epithelia has been identified in both mouse and human BA [23], as well as in other autoimmune biliary diseases [23,24], lending further evidence to the role of autoimmunity in the pathogenesis of BA.

In this study, we explored the role of B cells in the development of bile duct injury and obstruction in the mouse model of BA through the use of mb-1/CD79A gene knockout $\left(\lg -\alpha^{-l}\right)$ mice [25]. These mice have loss of $B$ cell receptor expression and function and are unable to present antigen or produce immunoglobulin [25-27]. In some autoimmune disease models, $\mathrm{B}$ cells have been shown to play an important role as antigen presenting cells that activate $T$ cells $[18,20]$. Therefore, a sub aim of this study was to determine the effect of $B$ cells on $C D 4^{+}$Th1 cytokine response, as a marker of $T$ cell activation, in this model.

\section{Methods}

\section{Mice}

All animals were housed and handled in accordance with criteria outlined in the NIH "Guide for Care and Use of Laboratory Animals" (publication \#86-23 revised 1985) through the UC Denver Office of Laboratory Animal Medicine. The study was approved by the University of Colorado Institutional Animal Care and Use Committee. All efforts were made to ameliorate animal suffering. Animal sacrifice was performed by CO2 asphyxiation followed by decapitation for neonates and cervical dislocation for adult mice. Timed pregnant female $\mathrm{BALB} / \mathrm{c}$ mice were purchased from rotavirus-free colonies of Jackson Laboratory (Bar Harbor, ME). Ig- $\alpha^{-1-}$ mice [25] on the BALB/c background were a gift from Roberta Pelanda, PhD (National Jewish Health, Denver, CO). Mice were given a single intraperitoneal (i.p.) injection of RRV $\left(1.5 \times 10^{6} \mathrm{pfu} / \mathrm{mL}\right)$ or balanced salt solution (BSS) within 24 hours of life. Animals were assessed each morning for jaundice in non-fur bearing regions. If animals were noted to display pain, severe distress, suffering, or impending death, they were euthanized immediately. Surviving animals were sacrificed at day 14 and pooled tissues from 3-8 mice were analyzed (minimum 3 pools/ experiment). For experiments involving Treg depletion, lg- $\alpha^{-/-}$mice were also given i.p. PC61 (gift from Ron Gill, PhD, Department of Transplant Immunology, University of Colorado, Aurora, CO) or rat serum control. All efforts were made to minimize animal suffering. Animal sacrifice was performed by $\mathrm{CO}_{2}$ asphyxiation followed by decapitation for neonates and cervical dislocation for adult mice.

\section{Tissue histology}

Tissue was formalin fixed, paraffin embedded, and stained with hematoxylin-eosin. Digital photographs were obtained using the Olympus BX41 microscopes (Melville, NY).

\section{Infectious Plaque Assay}

Liver tissue was homogenized in $100 \% \mathrm{w} / \mathrm{v}$ BSS and virus concentration was determined by plaque assay as previously described [13].

\section{Immunohistochemistry}

Liver tissue sections ( $7 \mu \mathrm{m}$ thick) were stained with FITCconjugated antibodies to CD3 or CD11b (eBiosciences, San Diego, CA) and Alexafluor 555-conjugated cytokeratin 19 using standard protocols [28].

\section{Serum direct bilirubin and immunoglobulin}

Serum direct bilirubin levels were determined with the Direct Bilirubin Test (Diagnostic Chemicals Ltd., Charlottetown, Canada). Serum IgG and IgM levels were determined via ELISA according to manufacturer's instructions (Kirkegaard \& Perry Laboratories, Gaithersburg, MD) (Pooled sera from 3 separate experiments).

\section{Isolation of Immune Cells from Tissue and Flow Cytometric Analysis}

Tissue was homogenized and red cells lysed with ACK buffer. Liver immune cells were enriched by Percoll gradient (40/60). Single-cell suspensions were incubated with Fc-block and stained with the following fluorochrome-conjugated antibodies (eBioscience, San Diego, CA): CD45, CD3, CD4, CD8, CD11B, B220, IgM, CD19, NKG2D, Foxp3, CD25, $\mathrm{CD} 11 \mathrm{C}$, or isotype matched controls. A mouse regulatory $\mathrm{T}$ cell (Treg) staining kit was used according to the manufacturer's instructions (eBioscience, San Diego, CA). Cells were visualized with FACS Caliber flow cytometer (BectonDickinson, Mountain View, CA) using FlowJo (Tree Star, Inc., Ashland, OR) software for analysis.

\section{Intracellular cytokine analysis by flow cytometry}

Hepatic immune cells were incubated with Brefeldin A. For some experiments, cells were stimulated with phorbol 12myristate 13-acetate (PMA) and ionomycin. All cells were incubated with fluorochrome-conjugated antibodies (eBioscience, San Diego, CA, USA): CD45.2, CD4, CD8, CD11B, or CD25 followed by permeabilization and intracellular staining for either: IL2, IL17, TNFa, IL10, or IFNy.

\section{Statistical analysis}

Values expressed as mean \pm standard deviation. One way analysis of variance (ANOVA) and Bonferroni's correction were used when more than two groups of mice were compared. The $t$ test was used for comparison between two groups. PRISM Graph Pad software (La Jolla, CA, USA) was employed for statistical analysis and creation of Kaplan-Meier curves. Differences in means were considered significant for $p$ values $<0.05$. 
A
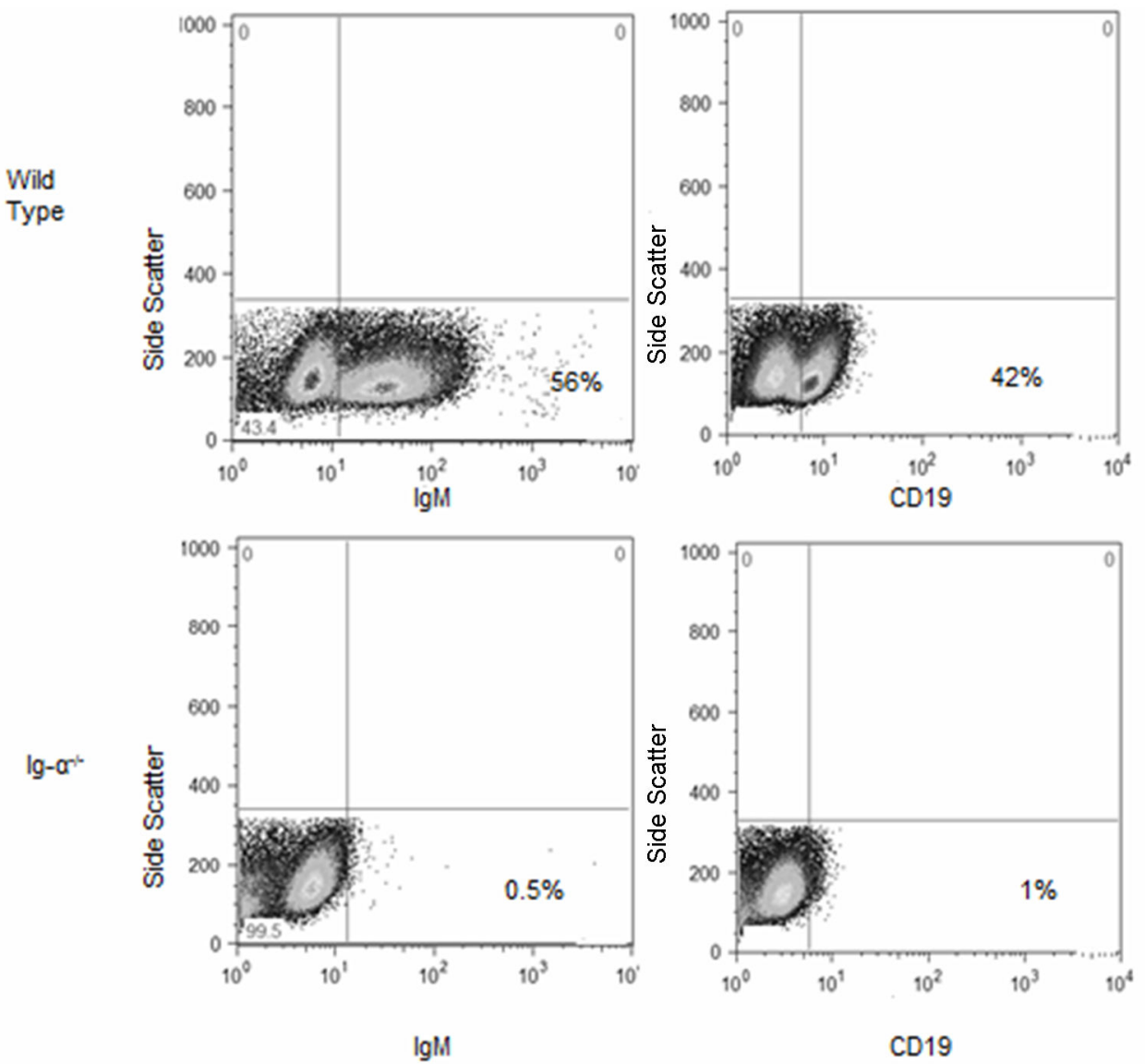

Figure 1. Characterization of lg- $\boldsymbol{\alpha}^{-/-}$mice. Representative dot plots of B cell surface marker expression on splenocytes from WT and Ig- $\alpha^{-/-}$mice, confirming lack of B cells in Ig- $\alpha^{-/-}$mice.

doi: 10.1371/journal.pone.0073644.g001

\section{Results}

\section{Characterization of B cell knockout status in Ig- $\mathrm{\alpha}^{-1-}$ mice.}

The $B$ cell receptor $(B C R)$ is composed of membrane-bound Ig (that binds antigen) and the non-covalently associated signal transduction moiety $\mathrm{lg}-\alpha / \mathrm{lg}-\beta$ (that is necessary for $B$ cell activation). The BCR is expressed on the cell surface and is functional only when all components are present. The B cell

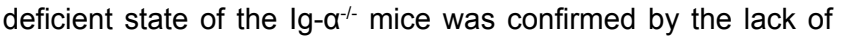
cells expressing CD19 and IgM (Figure 1) and by lack of serum $\lg M$ and $\lg G$ (data not shown).

\section{RRV infected $\mathrm{Ig}^{-\mathrm{\alpha}^{-/}}$mice are protected from developing BA}

Significantly improved disease-free survival rate was observed at 2 weeks of age in Ig- $^{-/-}$RRV-infected mice (76.8\%; $n=69)$ compared to WT RRV-infected mice $(17.5 \%$; $n=63)(P<0.0001)$ (Figure 2A). The WT RRV-infected mice displayed extensive portal tract and extrahepatic bile duct inflammation and obstruction, a finding not seen in the $\mathrm{Ig}-\mathrm{a}^{-/-}$ RRV-infected mice (Figure 2B). Serum direct bilirubin levels were significantly lower in lg- $\alpha^{-/}$RRV-infected mice at 2 weeks of age (RRV-infected WT: $10.05 \pm 3.09 \mathrm{mg} / \mathrm{dL}$; RRV-infected lg$\alpha^{-1}: 0.41 \pm 0.49 \mathrm{mg} / \mathrm{dL}$ ) (Figure $2 \mathrm{C}$ ). To determine if RRV infection of the liver was altered in the $\lg ^{-\alpha^{-/}}$mice, infectious plaque assays were performed. At 1 week, WT and Ig- $\mathrm{\alpha}^{-1-}$ mice had similar levels of infectious virus and by 2 weeks both groups had undetectable virus (Figure 2D). These data suggest that $B$ cell deficient mice were protected from the inflammatorymediated biliary injury and obstruction associated with BA.

\section{RRV-infected Ig- $\alpha^{-/-}$mice have significantly decreased liver inflammatory cells and increased regulatory $T$ cells}

Based on our observation that $\mathrm{Ig}-\mathrm{a}^{-/}$mice were protected

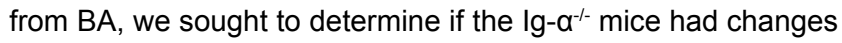
in the liver immune profile. The BSS $\mathrm{Ig}^{-\alpha^{-/}}$mice had similar amounts of liver $\mathrm{CD}^{+}$and $\mathrm{CD}^{+}{ }^{+} \mathrm{T}$ cells and $\mathrm{CD}^{+}{ }^{+} \mathrm{NKG} 2 \mathrm{D}^{+}$ natural killer (NK) $\mathrm{T}$ cells, and small decreases in CD11B 
A

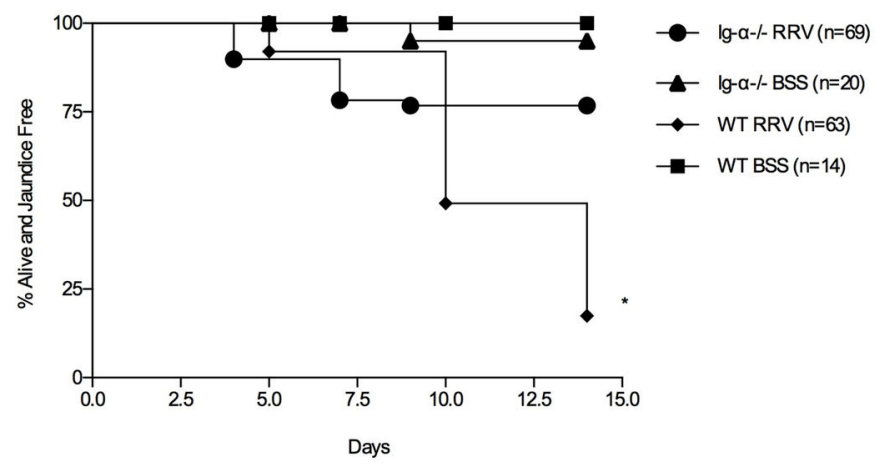

C

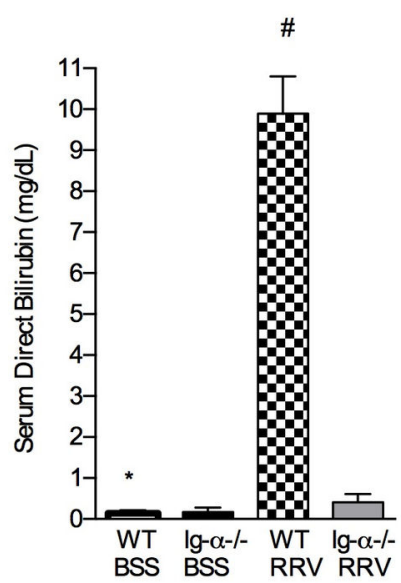

B

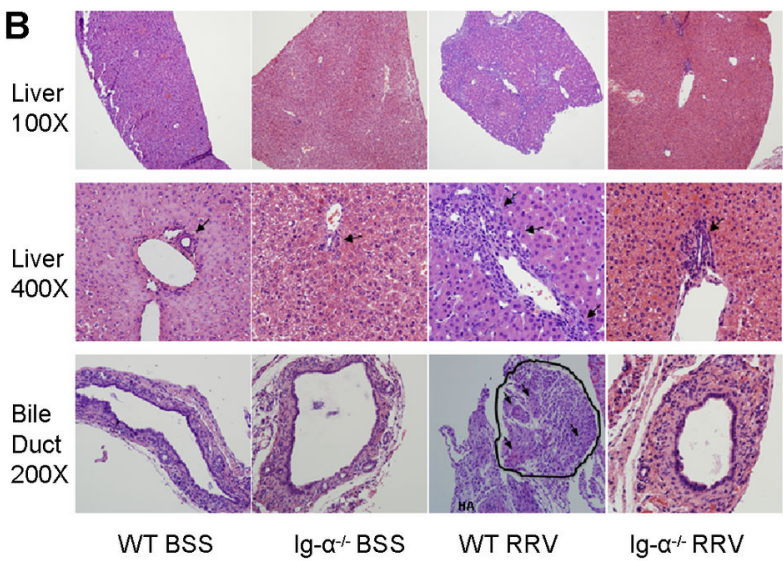

D

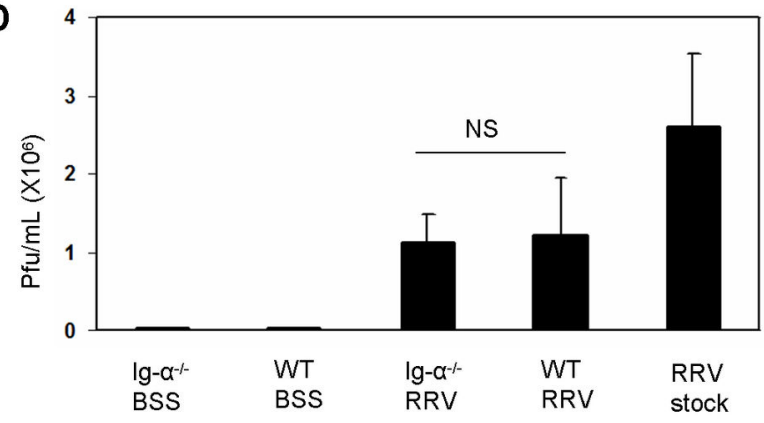

Figure 2. RRV-infected Ig- $\mathbf{\alpha}^{-/-}$mice do not develop bile duct inflammation and obstruction. (A) Disease free survival. Biliary disease was identified based on jaundice and acholic stools. ${ }^{*} \mathrm{P}<.001 \mathrm{vs}$. Ig- $\alpha^{-/-}$RRV mice. (B) Histology. H\&E staining from liver and extrahepatic bile ducts (arrows denote bile duct epithelia). 100x: The WT RRV liver inflammation extends between portal tracts. 200x: The WT RRV bile duct obstruction is not seen in the Ig- $\alpha^{--}$RRV mice (HA: hepatic artery). (C) Serum direct bilirubin. ${ }^{*} P<.001$ vs. WT RRV; \#P < .001 vs. Ig- $\alpha^{-/}$RRV. (D) Infectious plaque assay. Quantification of infectious virus from 1 week old liver homogenates (mean \pm SD pfu/ml).

doi: 10.1371/journal.pone.0073644.g002

${ }^{+}$macrophages and NKG2D + NK cells compared to BSS WT mice. The RRV-infected Ig- $\alpha^{-/-}$mice had significantly decreased numbers of $\mathrm{CD}^{+} \mathrm{T}$ cells $(\mathrm{P}<0.01), \mathrm{CD} 11 \mathrm{~B}^{+}$macrophages $(\mathrm{P}$ $<0.001), \mathrm{NKG}_{2} \mathrm{D}+\mathrm{NK}$ cells $(\mathrm{P}<0.01)$, and CD3+NKG2D + NK T cells $(P<0.001)$ compared to RRV-infected WT mice (Figure 3A). Immunohistochemistry revealed periductal infiltrates of $\mathrm{CD}^{+} \mathrm{T}$ cells and $\mathrm{CD} 11 \mathrm{~B}^{+}$macrophages in RRV-infected WT but not Ig- $\alpha^{-/-} R R V$-infected mice (Figure 3B). These results confirm that RRV-infected Ig- $\mathrm{\alpha}^{-/-}$mice do not develop bile ducttargeted inflammation.

Autoimmune diseases are often associated with defects in Treg number and function. Other models of autoimmune disease have identified that $B$ cell depletion results in an increased quantity of Tregs [17,29-31]. Therefore, we sought

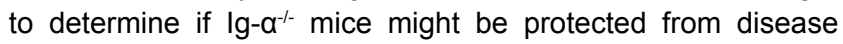

because of increased levels of Tregs. Increased levels of $\mathrm{CD}^{+}{ }^{+} \mathrm{CD} 25^{+} \mathrm{Foxp}^{+}$Tregs were identified in BSS-Ig- $\mathrm{C}^{-/-}$mice $(14.76 \pm 4.85 \%)$ compared to BSS-WT at 2 weeks of age $(7.24 \pm$ $2.56 \%) \quad(\mathrm{P}<0.001)$. After RRV infection, Tregs remained

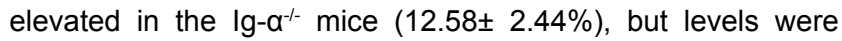
significantly lower in WT $(5.24 \pm 1.87 \%)(\mathrm{P}<0.001)$ (Figure $4 \mathrm{~A}$ and $4 \mathrm{~B}$ ). To determine if this increased number of Tregs in Ig$\alpha^{-/-}$mice was responsible for protection from biliary disease, we performed further experiments utilizing Treg-depleting antibodies (PC61). Neonatal Ig- $\alpha^{--}$mice received RRV at birth, followed by PC61 or rat serum (control) on day 4. Flow cytometry confirmed that mice receiving the PC61 injection were devoid of Tregs (Figure 5A). There was no significant change in disease-free survival between RRV-infected Ig- $\mathrm{\alpha}^{-1-}$ mice that received PC61 $(79.5 \%)$ versus control rat serum 


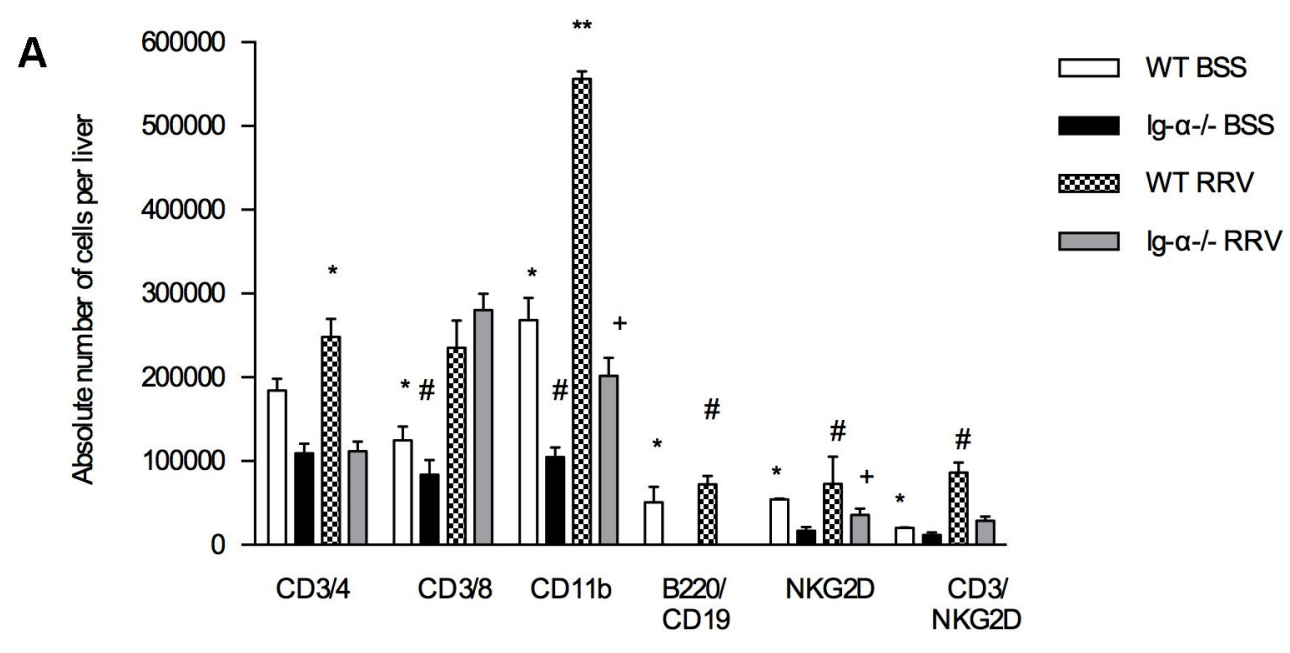

B

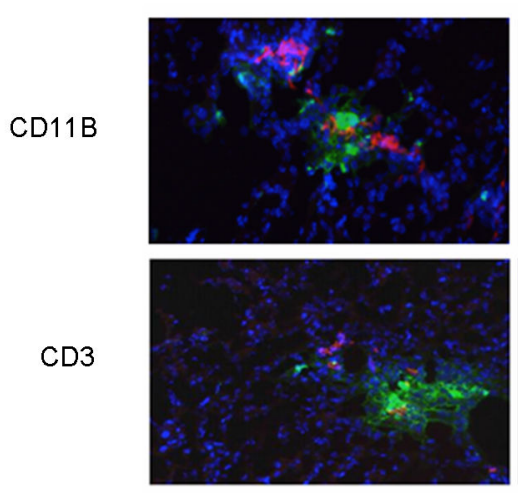

WT RRV
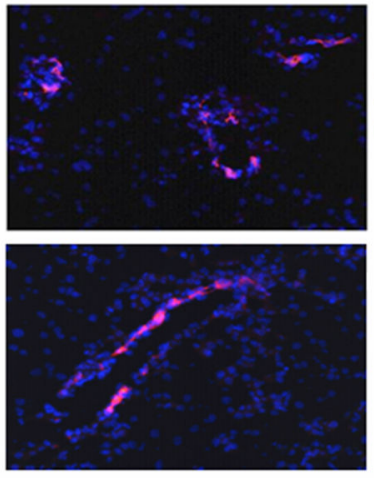

$\lg -\mathrm{Q}^{-t-\mathrm{RRV}}$

Figure 3. Livers of RRV infected Ig- ${ }^{-/}$mice have decreased pro-inflammatory cells. (A) Liver immune cell profile in 2 week old mice. Immune cells were identified based on CD45 expression. Shown is the mean $\pm S D$ absolute number of each immune cell subset per liver. CD3/4: * P<.01 vs. Ig- $\alpha-/-$ RRV; CD3/8: * P<.05 vs. WT RRV; \#P<.01 vs. Ig- $\alpha-/-$ RRV; CD11b: * P<.001 vs. Ig- $\alpha-/-$

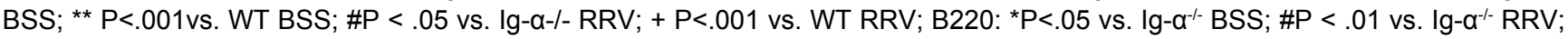
NKG2D: *P<.05 vs. Ig- ${ }^{-1-}$ BSS; \#P < 05 vs. WT BSS; +P <.01 vs. WT RRV; CD3/NKG2D: *P<.001 vs. WT RRV; \#P<.001 vs. Ig$\alpha^{-1-}$ RRV. (B) Liver immunohistochemistry. Liver tissue was incubated with anti-CD3 FITC (green-T cells), anti-CD11B FITC (greenmacrophages), anti-cytokeratin 19 AF555 (red- bile ducts) and Hoechst nuclear dye (blue).

doi: 10.1371/journal.pone.0073644.g003

(68.5\%). Likewise, there was no difference in serum direct bilirubin levels (Figure $5 \mathrm{~B}$ ) or liver immune cell populations (Figure 5C) between RRV-infected $\lg ^{-\alpha^{-/}}$mice that received PC61 versus control rat serum. Therefore, despite the increase in Tregs in $\mathrm{Ig}^{-\alpha^{-/}}$mice, these Treg depletion experiments show that Treg cell number was not solely responsible for protection from BA.

\section{Lack of B cell antigen presentation in Ig- $\alpha^{-/-}$mice is associated with marked attenuation of $\mathrm{CD}^{+}$Th1 cell activation}

In order for T cells to become activated, they must encounter and recognize antigen displayed on an antigen presenting cell. Professional antigen presenting cells include B cells, macrophages and dendritic cells. To determine if B cell antigen presentation was essential for $T$ cell activation in the mouse model of BA, we assessed the ability of $\mathrm{T}$ cells to become activated in the $\mathrm{Ig}^{-\alpha^{-1}}$ mice. The level of cytokine production from the liver immune cells was determined at baseline ("ex 


\section{A}
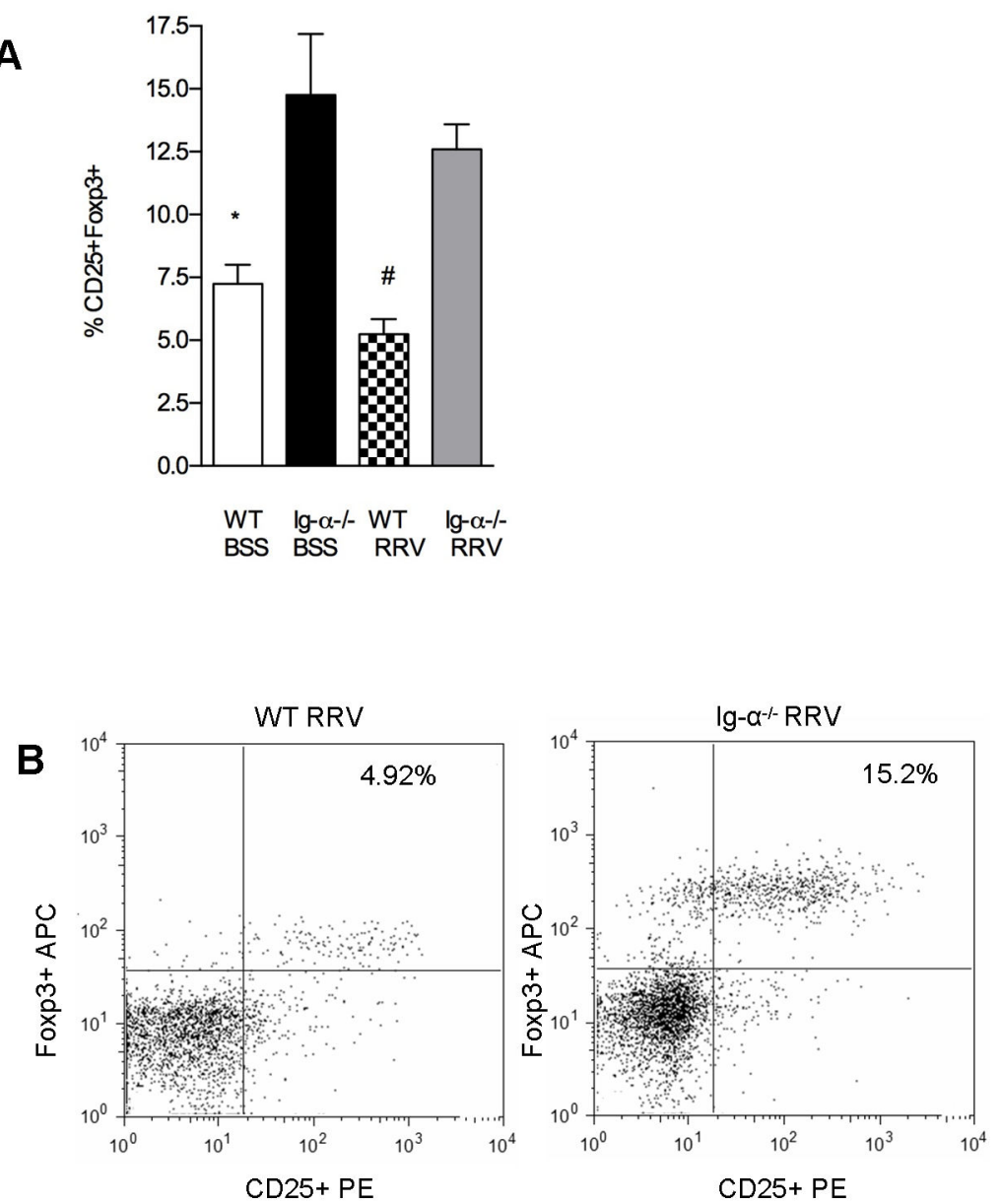

Figure 4. Livers of RRV infected Ig- ${ }^{-\%}$ mice have increased regulatory T cells. (A) Summary of liver Treg FACS analysis. Liver immune cells were stained for CD4, CD25 and intranuclear FoxP3. Shown is the percentage of the CD4 ${ }^{+}$population that were $\mathrm{CD}^{2}{ }^{+} \mathrm{Foxp}^{+}$(mean $\pm \mathrm{SD}$ ). ${ }^{*} \mathrm{P}<.001 \mathrm{vs}$. Ig- $\mathrm{\alpha}^{-/-} \mathrm{BSS}$; \#P < .001 vs. Ig- $\alpha^{-/-} \mathrm{RRV}$. (B) Representative Tregs dot plots. Shown are representative flow cytometry dot plots of liver Tregs (gated on CD4 ${ }^{+}$cells).

doi: 10.1371/journal.pone.0073644.g004

vivo") and after in vitro stimulation (PMA/ionomycin). Ex vivo analysis reflects the degree of cytokine production at a single time point while in vitro stimulation assesses the maximum potential of the immune cell to generate cytokines, reflecting the level of previous immune cell activation. Ex vivo analysis demonstrated significantly diminished numbers of $\mathrm{CD}^{+} \mathrm{T}$ cells producing IFN-Y $(\mathrm{P}=0.001), \mathrm{CD}^{+} \mathrm{T}$ cells producing IFN- $\mathrm{Y}$ $(P=0.001)$, and $C^{2} 11 B^{+}$macrophages generating TNF- $\alpha$

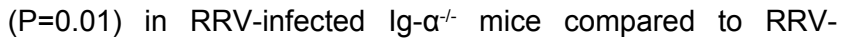
infected WT (Figure 6A). Liver immune cells from RRV-infected $\lg -\alpha^{-1-}$ mice that were stimulated with $\mathrm{PMA} /$ ionomycin in vitro also had significantly decreased $\mathrm{CD}^{+} \mathrm{T}$ cells producing IFN- $\gamma$ $(P<0.001)$ and TNF- $\alpha(P<0.001), C D 8^{+} T$ cells producing IFN- $\gamma$ $(P=0.001)$, and $C_{111 B^{+}}$macrophages producing TNF- $\alpha$ $(P<0.05)$ (Figure $6 B)$. There was no significant difference in production of IL2, IL10 or IL17 in ex vivo or in vitro analyses (data not shown). These data show that in the absence of $B$ cell antigen presentation, effector $\mathrm{T}$ cells (and downstream

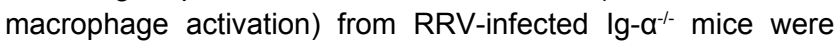

markedly less activated, resulting in lack of Th1 inflammatory injury to bile ducts.

\section{Discussion}

In the present study, we demonstrate that $B$ cell deficient mice are protected from developing BA, suggesting an essential role for $B$ cells in the pathogenesis of RRV-induced $\mathrm{BA}$ in mice. The diminished $\mathrm{T}$ cell activation in the setting of a $B$ cell-deficient host suggests that the mechanism of disease protection involves lack of $B$ cell antigen presentation. A summary of the proposed mechanism of action of $B$ cells in murine BA is shown in Figure 7. Limitations to this study include the fact that macrophage numbers were mildly decreased in the ${\lg -\alpha^{-/-}}$mice, possibly contributing to diminished antigen presentation. In addition, B cells secrete lymphotoxin which is required for proper lymphoid development and, together with other B cell factors, regulates dendritic cell and $\mathrm{T}$ cell interactions [32]. Saxena et al. has demonstrated 

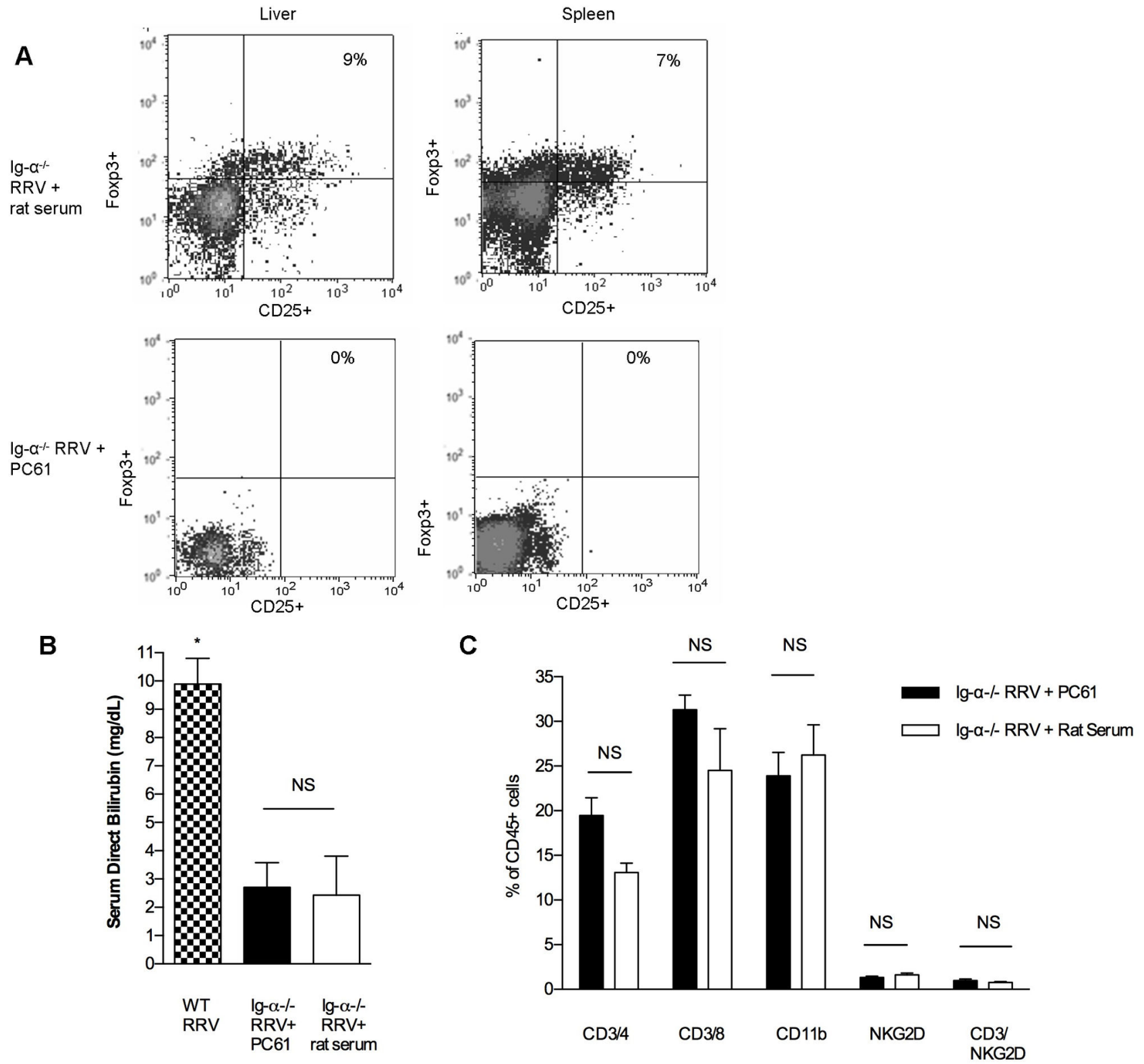

Figure 5. Treg depletion does not induce disease in RRV-infected Ig- $\alpha^{-1}$ mice. (A) Successful depletion of Tregs in lg- $\alpha^{-1}$ mice. PC61 (anti-CD25 depleting antibody) was administered to RRV-infected mice on day of life 4. Representative dot plots show

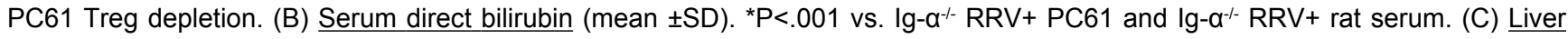
immune cell profile. Mice were sacrificed at 2 weeks of age and immune cells were identified based on CD45 expression.

doi: 10.1371/journal.pone.0073644.g005

that primed dendritic cells are required for the proliferation of $\mathrm{T}$ lymphocytes and the activation of NK cells in experimental BA [33].

B cells have been shown to be critical in the development and maintenance of multiple autoimmune diseases $[17,19,20,34,35]$. In a recent study by Chan et al. [36], mice unable to secrete immunoglobulin still developed lupus nephritis, suggesting that the role of B cells in autoimmune nephritis extends beyond autoantibody production and includes antigen presentation function. B cells are unique in their ability to stimulate autoimmune responses. Unlike other professional antigen cells which recognize molecular patterns from an antigen as foreign, the $\mathrm{B}$ cell receptor cannot distinguish between self and foreign antigens. Therefore, they are able to present self antigens to CD4 T cells and initiate an autoreactive immune response. Additionally, the B cell receptor's high affinity for a specific antigen allows for efficient processing of even small amounts of antigen that escape sequestration from 


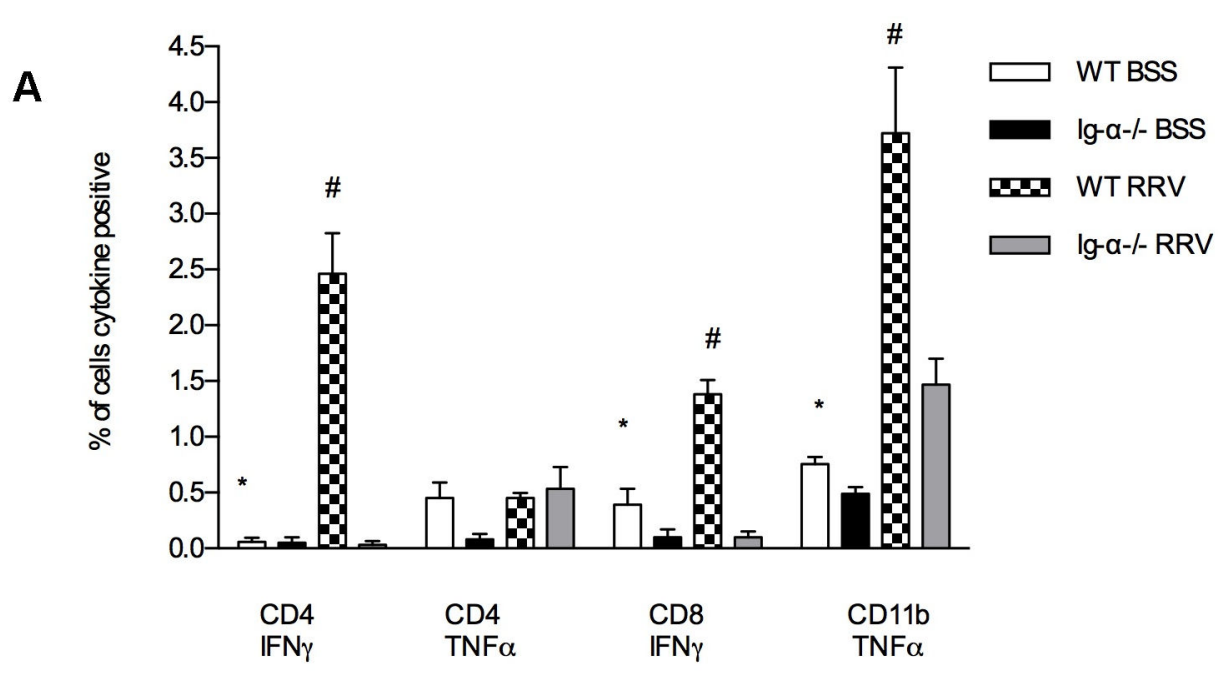

B

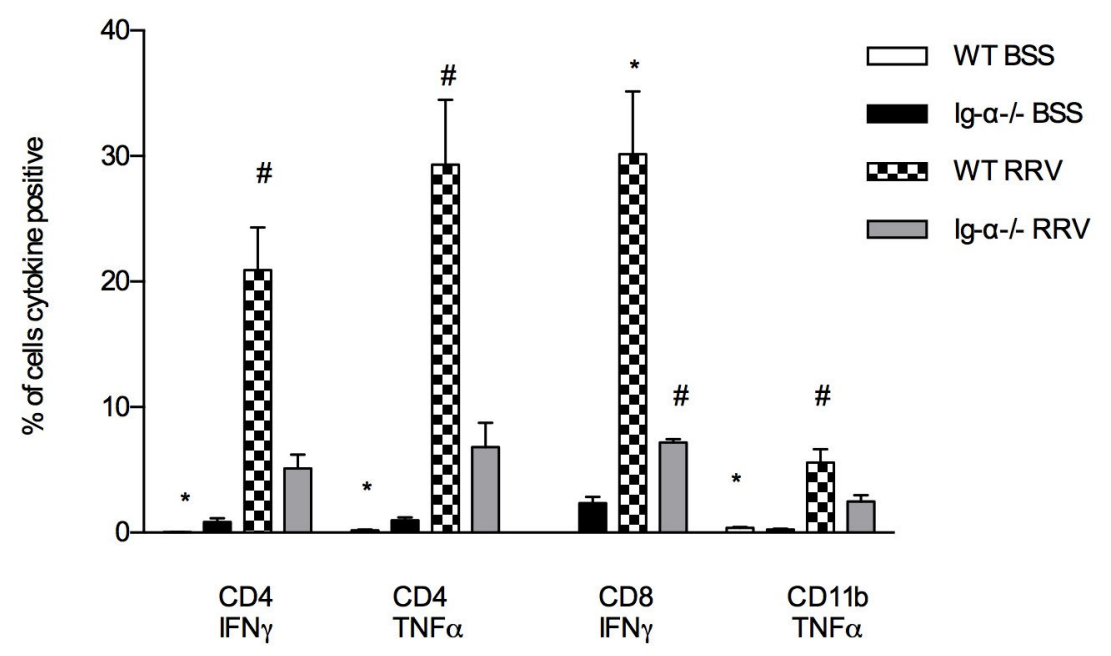

Figure 6. Livers of Ig- $\alpha^{-1-}$ mice have decreased Th1 cell cytokine production. (A) Ex-vivo baseline Th1 cytokine production. Hepatic immune cells were incubated with Brefeldin A to measure baseline cytokine response from $T$ cells. CD4-IFNy: ${ }^{*} P<.001$ vs. WT RRV; \#P <.001 vs. Ig- $\alpha^{-/-}$RRV; CD8-IFNY: ${ }^{*}<.001$ vs. WT RRV; \#P <.001 vs. Ig- $\alpha^{-/-}$RRV; CD11b-TNFa: ${ }^{*}<<.001$ vs. WT RRV; \#P $<.01$ vs. Ig- ${ }^{-/-}$RRV. (B) In vitro stimulation of Th1 cytokine production. Cells were incubated with Brefeldin A followed by stimulation with PMA/ionomycin. CD4-IFNY: ${ }^{*}$ P<.001 vs. WT RRV; \#P <.001 vs. Ig- $\mathrm{a}^{-/} \mathrm{RRV}$; CD4-TNFa: ${ }^{*} \mathrm{P}<.001 \mathrm{vs}$. WT RRV; \#P $<.001$ vs. Ig- $\alpha^{--}$RRV; CD8-IFNY: ${ }^{*}<.001$ vs. WT BSS; \#P <.001 vs. WT RRV; CD11b-TNFa: ${ }^{*} P<.001$ vs. WT RRV; \#P<.05 vs. Ig- $\alpha^{-/-}$RRV.

doi: 10.1371/journal.pone.0073644.g006

the immune system. Finally, the processing of autoantigen by $B$ cells is required for epitope spreading, which results in augmentation of an autoimmune response [37]. The essential role of antigen-specific B cells as antigen presenting cells has been demonstrated in the mouse models of systemic lupus erythematosus [38], diabetes [20,39,40], and autoimmune arthritis [19] where B cells are necessary for the activation of autoreactive $\mathrm{T}$ cells. In the animal model of multiple sclerosis, non-B antigen presenting cells can process and present antigenic protein, but are not able to induce the same pathogenic immune response initiated when B cells present antigen [41]. Several murine experimental models have demonstrated that $B$ cell deficiency results in failure to prime $\mathrm{CD}^{+} \mathrm{T}$ cells $[42,43]$. Autoantigen-specific $\mathrm{B}$ cells have been shown to improve Th1 [44,45], Th2 [46], and memory responses [47]. In addition, B cells have been shown to express a number of co-stimulatory molecules which reinforce priming and reactivation of antigen-specific $T$ cells $[48,49]$. The 
Figure 7.
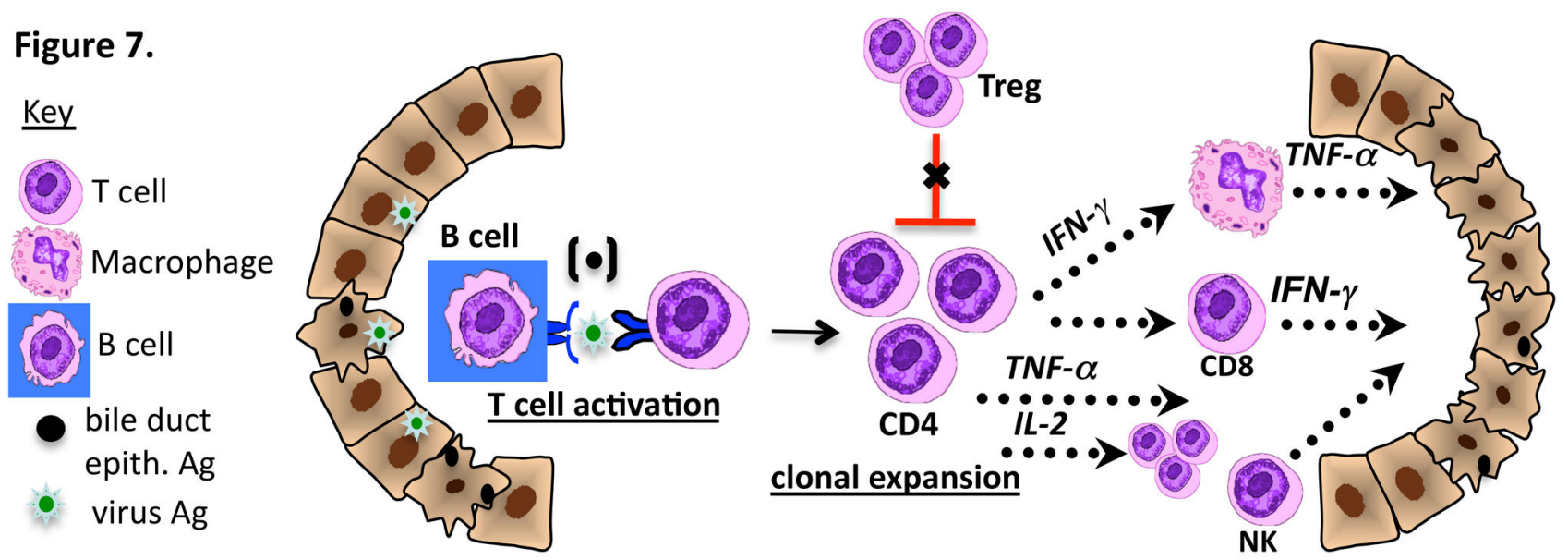

Figure 7. Proposed contribution of B cells to immune-mediated bile duct injury in biliary atresia. Based on the findings from B cell deficient mice, B cells may function as important antigen presenting cells that present virus or bile duct epithelial antigens (Ag) to naïve $\mathrm{CD}^{+} \mathrm{T}$ cells with subsequent $\mathrm{T}$ cell activation and clonal expansion. Activated Th1 cells: secrete IFN- $\gamma$ leading to macrophage stimulation; stimulate cytotoxic $\mathrm{CD}^{+} \mathrm{T}$ cells; secrete cytotoxic TNF- $\alpha$ and secrete IL-2, leading to further $\mathrm{T}$ cell expansion. In addition, B cell activation may inhibit Treg expansion, leading to diminished inhibition of $\mathrm{T}$ cell-mediated bile duct injury.

doi: 10.1371/journal.pone.0073644.g007

findings of this study corroborate the important role of B cells in inflammatory mediated bile duct injury in the RRV mouse model of BA.

Tregs function to suppress inflammation as well as autoreactive $\mathrm{T}$ cells that escape into the periphery. Quantitative and qualitative reduction of Tregs has been demonstrated in multiple inflammatory and autoimmune diseases [50-52], including both the mouse model and human studies of BA [53-55]. A link between B cells and Treg activity has been suggested in the mouse model of Crohn's disease where B cells worsen ileitis through suppression of Treg function [56]. Interestingly, in multiple animal models as well as clinical studies of other autoimmune diseases, B cell depletion has resulted in an increased quantity and improved suppressive abilities of Tregs [17,29-31]. In this study, we identified increased quantity of Tregs at baseline and after RRV infection in $B$ cell deficient mice. We initially hypothesized that this increased quantity of Tregs may have contributed to protection from disease. Although depletion of Tregs did not induce disease in ${\mathrm{Ig}-\mathrm{\alpha}^{-/}}^{-}$mice treated with PC61, these mice did develop slightly higher serum bilirubin levels $(3 \mathrm{mg} / \mathrm{dl}$ compared to $<1 \mathrm{mg} / \mathrm{dL}$ ) suggesting some degree of biliary injury, though not enough to lead to complete biliary obstruction. Therefore, while increased quantity of Tregs in Ig$\mathrm{a}^{-1-}$ mice was not solely responsible for protection from disease, it may play a minor role.

\section{References}

1. Mack CL, Feldman AG, Sokol RJ (2012). Clues to the etiology of bile duct injury in biliary atresia. Semin Liver Dis. 32(4):307-16.

2. Mack CL (2007) The pathogenesis of biliary atresia: evidence for a virus-induced autoimmune disease. Semin Liver Dis 27: 233-242. doi: 10.1055/s-2007-985068. PubMed: 17682970.
This is the first study to demonstrate that B cell deficient mice are protected against bile duct injury and obstruction in the RRV-induced mouse model of BA. These findings have important clinical implications. If $B$ cells are required to activate $\mathrm{CD}^{+} \mathrm{T}$ cells and perpetuate ongoing inflammation and bile duct injury, then strategies to deplete or inhibit B cell function might ameliorate bile duct targeted inflammation and could potentially delay or prevent the need for liver transplantation in children with BA. B cell directed therapies have yielded promising results in cohorts of patients with rheumatoid arthritis [57], multiple sclerosis [58,59], and type 1 diabetes mellitus [60] confirming the important role of $\mathrm{B}$ cells in pathogenesis of human autoimmune disease. Further exploration of the mechanisms by which B-cell depletion may be protective in human BA are indicated.

\section{Author Contributions}

Conceived and designed the experiments: AF RT EF RP CM. Performed the experiments: AF RT EF RP CM. Analyzed the data: AF RT EF RP CM. Contributed reagents/materials/ analysis tools: AF RT EF RP CM. Wrote the manuscript: AF RT EF RP CM. 
4. Lykavieris P, Chardot C, Sokhn M, Gauthier F, Valayer J et al. (2005) Outcome in adulthood of biliary atresia: a study of 63 patients who survived for over 20 years with their native liver. Hepatology 41 : 366-371. doi:10.1002/hep.20547. PubMed: 15660386.

5. Sokol RJ, Mack C, Narkewicz MR, Karrer FM (2003) Pathogenesis and outcome of biliary atresia: current concepts. J Pediatr Gastroenterol Nutr 37: 4-21. doi:10.1097/00005176-200307000-00003. PubMed: 12827000.

6. Riepenhoff-Talty M, Gouvea V, Evans MJ, Svensson L, Hoffenberg E et al. (1996) Detection of group $C$ rotavirus in infants with extrahepatic biliary atresia. J Infect Dis 174: 8-15. doi:10.1093/infdis/174.1.8. PubMed: 8656017

7. Tyler KL, Sokol RJ, Oberhaus SM, Le M, Karrer FM et al. (1998) Detection of reovirus RNA in hepatobiliary tissues from patients with extrahepatic biliary atresia and choledochal cysts. Hepatology 27: 1475-1482. doi:10.1002/hep.510270603. PubMed: 9620316.

8. Jevon GP, Dimmick JE (1999) Biliary atresia and cytomegalovirus infection: a DNA study. Pediatr Dev Pathol 2: 11-14. doi:10.1007/ s100249900083. PubMed: 9841700.

9. Schreiber RA, Kleinman RE (1993) Genetics, immunology, and biliary atresia: an opening or a diversion? J Pediatr Gastroenterol Nutr 16: 111-113. doi:10.1097/00005176-199302000-00001. PubMed: 8450373.

10. Tan CE, Driver M, Howard ER, Moscoso GJ (1994) Extrahepatic biliary atresia: a first-trimester event? Clues from light microscopy and immunohistochemistry. J Pediatr Surg 29: 808-814. doi: 10.1016/0022-3468(94)90377-8. PubMed: 7521396.

11. Riepenhoff-Talty M, Schaekel K, Clark HF, Mueller W, Uhnoo I et al. (1993) Group A rotaviruses produce extrahepatic biliary obstruction in orally inoculated newborn mice. Pediatr Res 33: 394-399. doi: 10.1203/00006450-199333040-00016. PubMed: 8386833.

12. Petersen C, Grasshoff S, Luciano L (1998) Diverse morphology of biliary atresia in an animal model. J Hepatol 28: 603-607. doi:10.1016/ S0168-8278(98)80283-3. PubMed: 9566828

13. Mack CL, Tucker RM, Sokol RJ, Kotzin BL (2005) Armed CD4+ Th1 effector cells and activated macrophages participate in bile duct injury in murine biliary atresia. Clin Immunol 115: 200-209. doi:10.1016/j.clim. 2005.01.012. PubMed: 15885644.

14. Shivakumar $P$, Campbell KM, Sabla GE, Miethke A, Tiao $G$ et al. (2004) Obstruction of extrahepatic bile ducts by lymphocytes is regulated by IFN-gamma in experimental biliary atresia. J Clin Invest 114: 322-329. doi:10.1172/JCl200421153. PubMed: 15286798.

15. Mack CL, Tucker RM, Lu BR, Sokol RJ, Fontenot AP et al. (2006) Cellular and humoral autoimmunity directed at bile duct epithelia in murine biliary atresia. Hepatology 44: 1231-1239. doi:10.1002/hep. 21366. PubMed: 17058262.

16. Shivakumar P, Sabla G, Mohanty S, McNeal M, Ward R et al. (2007) Effector role of neonatal hepatic CD8+ lymphocytes in epithelial injury and autoimmunity in experimental biliary atresia. Gastroenterology 133 : 268-277. doi:10.1053/j.gastro.2007.04.031. PubMed: 17631148.

17. Yu S, Maiti PK, Dyson M, Jain R, Braley-Mullen H (2006) B celldeficient NOD.H-2h4 mice have CD4+CD25+ $T$ regulatory cells that inhibit the development of spontaneous autoimmune thyroiditis. J Exp Med 203: 349-358. doi:10.1084/jem.20051438. PubMed: 16446379.

18. Chan O, Shlomchik MJ (1998) A new role for B cells in systemic autoimmunity: B cells promote spontaneous $\mathrm{T}$ cell activation in MRLIpr/lpr mice. J Immunol 160: 51-59. PubMed: 9551955.

19. O'Neill SK, Shlomchik MJ, Glant TT, Cao Y, Doodes PD et al. (2005) Antigen-specific B cells are required as APCs and autoantibodyproducing cells for induction of severe autoimmune arthritis. J Immunol 174: 3781-3788. PubMed: 15749919.

20. Serreze DV, Fleming SA, Chapman HD, Richard SD, Leiter EH et al. (1998) B lymphocytes are critical antigen-presenting cells for the initiation of $\mathrm{T}$ cell-mediated autoimmune diabetes in nonobese diabetic mice. J Immunol 161: 3912-3918. PubMed: 9780157.

21. Levesque MC, St Clair EW (2008) B cell-directed therapies for autoimmune disease and correlates of disease response and relapse. J Allergy Clin Immunol 121: 13-21; quiz 22-13 doi:10.1016/j.jaci. 2007.12.053. PubMed: 18206502.

22. Hadchouel M, Hugon RN, Odievre M (1981) Immunoglobulin deposits in the biliary remnants of extrahepatic biliary atresia: a study by immunoperoxidase staining in 128 infants. Histopathology 5: 217-221. doi:10.1111/j.1365-2559.1981.tb01779.x. PubMed: 7216182.

23. Lu BR, Brindley SM, Tucker RM, Lambert CL, Mack CL (2010) Alphaenolase autoantibodies cross-reactive to viral proteins in a mouse model of biliary atresia. Gastroenterology 139: 1753-1761. doi:10.1053/ j.gastro.2010.07.042. PubMed: 20659472.

24. Vermeulen N, de Béeck KO, Vermeire S, Van Steen K, Michiels G et al. (2011) Identification of a novel autoantigen in inflammatory bowel disease by protein microarray. Inflamm Bowel Dis 17: 1291-1300. doi: 10.1002/ibd.21508. PubMed: 21560193.

25. Pelanda R, Braun U, Hobeika E, Nussenzweig MC, Reth M (2002) B cell progenitors are arrested in maturation but have intact VDJ recombination in the absence of Ig-alpha and Ig-beta. J Immunol 169: 865-872. PubMed: 12097390.

26. Minegishi Y, Coustan-Smith E, Rapalus L, Ersoy F, Campana D et al. (1999) Mutations in Igalpha (CD79a) result in a complete block in B-cell development. J Clin Invest 104: 1115-1121. doi:10.1172/JCI7696. PubMed: 10525050.

27. Gong S, Nussenzweig MC (1996) Regulation of an early developmental checkpoint in the B cell pathway by Ig beta. Science 272: 411-414. doi: 10.1126/science.272.5260.411. PubMed: 8602530 .

28. Barnes BH, Tucker RM, Wehrmann F, Mack DG, Ueno Y et al. (2009) Cholangiocytes as immune modulators in rotavirus-induced murine biliary atresia. Liver Int 29: 1253-1261. doi:10.1111/j. 1478-3231.2008.01921.x. PubMed: 19040538

29. Stasi R, Cooper N, Del Poeta G, Stipa E, Laura Evangelista M et al. (2008) Analysis of regulatory T-cell changes in patients with idiopathic thrombocytopenic purpura receiving B cell-depleting therapy with rituximab. Blood 112: 1147-1150. doi:10.1182/blood-2007-12-129262. PubMed: 18375792

30. Hamel KM, Cao Y, Ashaye S, Wang Y, Dunn R et al.. (2011) B cell depletion enhances $T$ regulatory cell activity essential in the suppression of arthritis. J Immunol 187: 4900-4906. doi:10.4049/ jimmunol.1101844. PubMed: 21948985.

31. Sfikakis PP, Souliotis VL, Fragiadaki KG, Moutsopoulos HM, Boletis JN et al. (2007) Increased expression of the FoxP3 functional marker of regulatory $T$ cells following $B$ cell depletion with rituximab in patients with lupus nephritis. Clin Immunol 123: 66-73. doi:10.1016/j.clim. 2007.03.366. PubMed: 17275413

32. Myers RC, King RG, Carter RH, Justement LB (2013) Lymphotoxin alpha(1) beta(2) expression on $B$ cells is required for follicular dendritic cell activation during the germinal center response. Eur J Immunol 43: 348-359. doi:10.1002/eji.201242471. PubMed: 23112125.

33. Saxena V, Shivakumar P, Sabla G, Mourya R, Chougnet C et al. (2011) Dendritic cells regulate natural killer cell activation and epithelial injury in experimental biliary atresia. Sci Transl Med 3: 102ra194. PubMed: 21957172.

34. Chan OT, Madaio MP, Shlomchik MJ (1999) B cells are required for lupus nephritis in the polygenic, Fas-intact MRL model of systemic autoimmunity. J Immunol 163: 3592-3596. PubMed: 10490951.

35. Braley-Mullen H, Yu S (2000) Early requirement for B cells for development of spontaneous autoimmune thyroiditis in NOD.H-2h4 mice. J Immunol 165: 7262-7269. PubMed: 11120860

36. Chan OT, Hannum LG, Haberman AM, Madaio MP, Shlomchik MJ (1999) A novel mouse with B cells but lacking serum antibody reveals an antibody-independent role for B cells in murine lupus. J Exp Med 189: 1639-1648. doi:10.1084/jem.189.10.1639. PubMed: 10330443.

37. Rodríguez-Pinto D (2005) B cells as antigen presenting cells. Cell Immunol 238: 67-75. doi:10.1016/j.cellimm.2006.02.005. PubMed: 16574086

38. Chan OT, Hannum LG, Haberman AM, Madaio MP, Shlomchik MJ (1999) A novel mouse with B cells but lacking serum antibody reveals an antibody-independent role for B cells in murine lupus. J Exp Med 189: 1639-1648. doi:10.1084/jem.189.10.1639. PubMed: 10330443.

39. Falcone M, Lee J, Patstone G, Yeung B, Sarvetnick N (1998) B lymphocytes are crucial antigen-presenting cells in the pathogenic autoimmune response to GAD65 antigen in nonobese diabetic mice. J Immunol 161: 1163-1168. PubMed: 9686575.

40. Noorchashm H, Lieu YK, Noorchashm N, Rostami SY, Greeley SA et al. (1999) I-Ag7-mediated antigen presentation by B lymphocytes is critical in overcoming a checkpoint in T cell tolerance to islet beta cells of nonobese diabetic mice. J Immunol 163: 743-750. PubMed: 10395666.

41. Lyons JA, San M, Happ MP, Cross AH (1999) B cells are critical to induction of experimental allergic encephalomyelitis by protein but not by a short encephalitogenic peptide. Eur J Immunol 29: 3432-3439. doi: 10.1002/(SICl)1521-4141(199911)29:11. PubMed: 10556797.

42. Ron Y, Sprent J (1987) T cell priming in vivo: a major role for B cells in presenting antigen to $T$ cells in lymph nodes. $J$ Immunol 138: 2848-2856. PubMed: 2952725.

43. Kurt-Jones EA, Liano D, HayGlass KA, Benacerraf B, Sy MS, et al (1988) The role of antigen-presenting $B$ cells in T cell priming in vivo. Studies of B cell-deficient mice. J Immunol 140: 3773-3778. PubMed: 2453554.

44. Barr TA, Brown S, Mastroeni P, Gray D. (2010) TLR and B cell receptor signals to $B$ cells differentially program primary and memory Th1 
responses to Salmonella enterica. J Immunol 185: 2783-2789. doi: 10.4049/jimmunol.1001431. PubMed: 20675594.

45. Mastroeni P, Simmons C, Fowler R, Hormaeche CE, Dougan G (2000) Igh-6(-/-) (B-cell-deficient) mice fail to mount solid acquired resistance to oral challenge with virulent Salmonella enterica serovar typhimurium and show impaired Th1 T-cell responses to Salmonella antigens. Infect Immun 68: 46-53. doi:10.1128/IAI.68.1.46-53.2000. PubMed: 10603367.

46. Linton PJ, Bautista B, Biederman E, Bradley ES, Harbertson J et al. (2003) Costimulation via OX40L expressed by B cells is sufficient to determine the extent of primary CD4 cell expansion and Th2 cytokine secretion in vivo. J Exp Med 197: 875-883. doi:10.1084/jem.20021290. PubMed: 12668647.

47. Linton PJ, Harbertson J, Bradley LM (2000) A critical role for B cells in the development of memory CD4 cells. J Immunol 165: 5558-5565. PubMed: 11067910.

48. Rodríguez-Pinto D, Moreno $\mathrm{J}$ (2005) B cells can prime naive CD4+ T cells in vivo in the absence of other professional antigen-presenting cells in a CD154-CD40-dependent manner. Eur J Immunol 35: 1097-1105. doi:10.1002/eji.200425732. PubMed: 15756646.

49. Sfikakis PP, Boletis JN, Lionaki S, Vigklis V, Fragiadaki KG et al. (2005) Remission of proliferative lupus nephritis following B cell depletion therapy is preceded by down-regulation of the $\mathrm{T}$ cell costimulatory molecule CD40 ligand: an open-label trial. Arthritis Rheum 52: 501-513. doi:10.1002/art.20858. PubMed: 15693003.

50. Viglietta V, Baecher-Allan C, Weiner HL, Hafler DA (2004) Loss of functional suppression by $C D 4+C D 25+$ regulatory $T$ cells in patients with multiple sclerosis. J Exp Med 199: 971-979. doi:10.1084/jem. 20031579. PubMed: 15067033.

51. Lawson CA, Brown AK, Bejarano V, Douglas $\mathrm{SH}$, Burgoyne $\mathrm{CH}$ et al. (2006) Early rheumatoid arthritis is associated with a deficit in the CD4+CD25high regulatory $T$ cell population in peripheral blood. Rheumatology (Oxf) 45: 1210-1217. doi:10.1093/rheumatology/kel089. PubMed: 16571607.

52. Lindley S, Dayan CM, Bishop A, Roep BO, Peakman M et al. (2005) Defective suppressor function in CD4(+)CD25(+) T-cells from patients with type 1 diabetes. Diabetes 54: 92-99. doi:10.2337/diabetes.54.1.92. PubMed: 15616015

53. Miethke AG, Saxena V, Shivakumar P, Sabla GE, Simmons J et al (2010) Post-natal paucity of regulatory I cells and control of NK cell activation in experimental biliary atresia. J Hepatol 52(5):718-26

54. Tucker RM, Feldman AG, Fenner EK, Mack CL (2013) Regulatory T cells inhibit Th1 cell-mediated bile duct injury in murine biliary atresia. $\mathrm{J}$ Hepatol [Epub ahead of print].

55. Brindley SM, Lanham AM, Karrer FM, Tucker RM, Fontenot AP, Mack CL (2012). Cytomegalovirus-specific T-cell reactivity in biliary atresia at the time of diagnosis is associated with deficits in regulatory $\mathrm{T}$ cells. Hepatology. 55(4):1130-8

56. Olson TS, Bamias G, Naganuma M, Rivera-Nieves J, Burcin TL et al. (2004) Expanded B cell population blocks regulatory $T$ cells and exacerbates ileitis in a murine model of Crohn disease. J Clin Invest 114: 389-398. doi:10.1172/JCI200420855. PubMed: 15286805.

57. Cohen SB, Emery P, Greenwald MW, Dougados M, Furie RA et al. (2006) Rituximab for rheumatoid arthritis refractory to anti-tumor necrosis factor therapy: Results of a multicenter, randomized, doubleblind, placebo-controlled, phase III trial evaluating primary efficacy and safety at twenty-four weeks. Arthritis Rheum 54: 2793-2806. doi: 10.1002/art.22025. PubMed: 16947627.

58. Hauser SL, Waubant E, Arnold DL, Vollmer T, Antel J et al. (2008) Bcell depletion with rituximab in relapsing-remitting multiple sclerosis. $\mathrm{N}$ Engl J Med 358: 676-688. doi:10.1056/NEJMoa0706383. PubMed: 18272891.

59. Bar-Or A, Calabresi PA, Arnold D, Markowitz C, Shafer S et al. (2008) Rituximab in relapsing-remitting multiple sclerosis: a 72-week, openlabel, phase I trial. Ann Neurol 63: 395-400. doi:10.1002/ana.21363. PubMed: 18383069.

60. Pescovitz MD, Greenbaum CJ, Krause-Steinrauf H, Becker DJ, Gitelman SE et al. (2009) Rituximab, B-lymphocyte depletion, and preservation of beta-cell function. N Engl J Med 361: 2143-2152. doi: 10.1056/NEJMoa0904452. PubMed: 19940299. 